\title{
TWO INTRATHECAL TRANSPLANTS OF BONE MARROW MONONUCLEAR CELLS PRODUCE MOTOR IMPROVEMENT IN AN ACUTE AND SEVERE MODEL OF SPINAL CORD INJURY
}

\author{
RECUPERAÇÃO MOTORA APÓS DOIS TRANSPLANTES DE CÉLULAS MONONUCLEARES DA \\ MEDULA ÓSSSEA ADMINISTRADOS NO ESPAÇO SUBARACNÓIDEO UTILIZANDO MODELO \\ DE LESÃO TRAUMÁTICA GRAVE DA MEDULA ESPINAL
}

\author{
RECUPERACIÓN MOTORA DESPUÉS DE DOS TRASPLANTES DE CÉLULAS MONONUCLEARES \\ DE LA MÉDULA ÓSEA, ADMINISTRADOS EN EL ESPACIO SUBARACNOIDEO, UTILIZANDO \\ MODELO DE LESIÓN AGUDA Y GRAVE DE LA MÉDULA ESPINAL
}

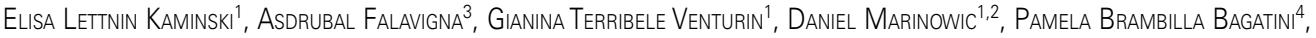
Léder Leal Xavier ${ }^{4}$, Jaderson Costa DaCosta ${ }^{1}$

\begin{abstract}
Objective: We studied transplants of bone marrow mononuclear cells (BMMC) by lumbar puncture (LP) in a severe model of spinal cord injury (SCl) using clip compression. Methods: BMMCs or saline solution were transplanted by LP 48 hours and 9 days post injury. Motor function was evaluated by BBB scale, histological analysis by Nissl technique and the verification of cell migration by PCR analysis. Results: The BBB had significantly improved in rats treated with BMMCs by LP compared with controls $(p<0.001)$. The histological analysis did not showed difference in the lesional area between the groups. The PCR analysis was able to found BMMCs in the injury site. Conclusions: two BMMC transplants by LP improved motor function in a severe model of SCl and BMMC was found in the injury site.
\end{abstract}

Keywords: Spinal cord injuries; Lumbar puncture; Bone marrow cells; Stem cells.

\section{RESUMO}

Objetivo: Estudamos transplantes de células mononucleares da medula óssea (CMMO) por punção lombar (PL) em um modelo de lesão da medula espinal (LME) grave usando compressão por clipe. Métodos: CMMOs ou solução salina foram transplantadas por PL 48 horas e 9 dias após a $L M E$. A função motora foi avaliada pela escala de BBB, a análise histológica pela técnica de Niss/ e a migração celular pela análise de reação em cadeia da polimerase (PCR). Resultados: A BBB demonstrou melhora significativa nos animais tratados com CMMOs por PL, em comparação com os controles $(p<0,001)$. A análise histológica não apresentou diferença entre as áreas de lesão dos grupos. CMMOs foram encontradas no local da lesão na análise de PCR. Conclusão: Dois transplantes de CMMOs por PL melhoraram a função motora em um modelo de LME grave. CMMOs foram encontradas no local da lesão.

Descritores: Lesões da medula espinal; Punção lombar; Células da medula óssea; Células-tronco.

\section{RESUMEN}

Objetivo: Estudiamos trasplantes de células mononucleares de la médula ósea (CMMO) por punción lumbar ( $P L)$ en un modelo de lesión de la médula espinal (LME) grave, usando compresión por clip. Métodos: CMMOs o solución salina fueron trasplantadas por PL, 48 horas y 9 días después de la $L M E$. La función motora fue evaluada por la escala de BBB, el análisis histológico por la técnica de Niss/ y la migración celular por el análisis de reacción en cadena de la polimerasa (PCR). Resultados. La BBB demostró mejoría significativa en los animales tratados con CMMOs por PL, en comparación con los controles ( $p<0,001)$. El análisis histológico no presentó diferencia entre las áreas de lesión de los grupos. CMMOs fueron encontradas en el lugar de la lesión en el análisis de PCR. Conclusión: Dos trasplantes de CMMOs por PL mejoraron la función motora en un modelo de LME grave. CMMOs fueron encontradas en el área de la lesión.

Descriptores: Lesiones de la médula espinal; Punción lumbar; Células de la médula ósea; Células-tronco.

\section{INTRODUCTION}

Spinal cord injuries (SCI) are devastating, and often affect young and healthy individuals. ${ }^{1} \mathrm{SCls}$ have a high incidence, between 1540 cases per million per year globally, and impose a heavy burden on government and society. ${ }^{2}$ New therapeutic strategies have been investigated to try to reduce the severe morbidity, such as the use of bone marrow stem cell (BMSC) transplantation. The use of BMSC presents advantages when compared with other cells types, be- cause these cells are easily expanded in vitro, there are no ethical issues regarding their use and no risk of rejection, since they are collected from the patient himself. ${ }^{3,4}$ Previous studies have presented benefits in their application in experimental SCI models showing an improvement in gait, migration to the lesion and differentiation into neurons and oligodendrocytes. ${ }^{5,6}$

One of the main factors in stem cell (SC) therapy is the route of cell delivery and the number of times SC should be administered during

1. Laboratório de Neurociências, Instituto de Pesquisas Biomédicas e Instituto do Cérebro, Pontifícia Universidade Católica do Rio Grande do Sul, Porto Alegre, RS, Brasil.

2. Laboratório de Terapia Celular, Instituto de Pesquisas Biomédicas e Instituto do Cérebro, Pontifícia Universidade Católica do Rio Grande do Sul, Porto Alegre, RS, Brasil.

3. Departamento de Neurocirurgia da Universidade de Caxias do Sul (UCS), Caxias do Sul, RS, Brasil.

4. Laboratório de Biologia Celular eTecidual, Departamento de Ciências Morfofisiológicas, Faculdade de Biociências, Pontifícia Universidade Católica do Rio Grande do Sul, Porto Alegre, RS, Brasil.

Study conducted Pontifícia Universidade Católica do Rio Grande do Sul, Porto Alegre, RS, Brasil.

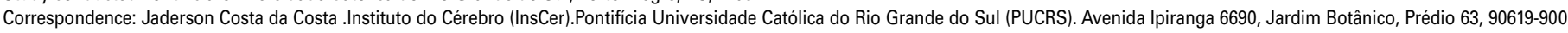
Porto Alegre, RS, Brasil. jcc@pucrs.br 
the window of opportunity. In animal models of $\mathrm{SCl}$, the most common mode of delivery is direct injection (DI) into the injury site, which allows a defined number of SC to be delivered. The clinical translation with the DI transplantation is not straightforward, because of the need for a new surgical procedure and the risk of further injuring the spinal cord. $^{7-9}$ Less invasive SC delivery methods need a more profound study. The intrathecal delivery by lumbar puncture (LP) is a minimally invasive approach that decreases the risk to the patient and allows delivery of multiple cell doses over a preplanned length of time. ${ }^{10-12}$

The efficacy of a single BMSC transplantation by LP was previously studied in mild $\mathrm{SCl}$ but showed marginal efficacy. ${ }^{13}$ We aimed to study the efficacy of two infusions of bone marrow mononuclear cells (BMMCs) by LP in a model of severe SCl.

\section{METHODS}

\section{Study design}

Eighteen female Wistar rats (60 days old) were used as recipients and 15 male Wistar rats (60 days old) were used as BMMCs donors. Animals were divided into 3 groups of 6 animals each: sham (controls); receiving BMMCs by LP; and receiving saline solution by LP.

On day 1, animals were subjected to $\mathrm{SCl}$. A motor function evaluation using the Basso, Beattie, and Bresnahan (BBB) scale was performed 24 hours later in order to have the BBB baseline or exclude the animals that presented a a BBB score higher than than 3 points. ${ }^{14}$ BMMCs or saline were administered by LP on day 3 and day 9 after SCl. All animals were given BBB scores on days 7, 14, and 21 after $\mathrm{SCl}$. After the last evaluation, they were euthanized and histologic analysis was performed. The experimental protocols used in this study followed international standards for animal testing, and were approved by the Animal Care and Ethics Committee of the Pontifical Catholic University of Rio Grande do Sul -PUCRS (CEUA 09/00109).

\section{Surgical Procedures}

Animals were weighed and anesthetized by intraperitoneal injection with $2 \%$ xylazine $(0.1 \mathrm{ml} / \mathrm{g})$ and $10 \%$ ketamine $(0.22 \mathrm{ml} / \mathrm{g})$. The rats were positioned in ventral decubitus and the skin over the thoracic spine was shaved and cleaned using antiseptic solution. The incision site was determined by palpation of the last rib and counting to define the eighth rib. A 3-cm incision at the midline over the dorsal region was performed with removal of paravertebral muscles and locating the vertebral lamina of the eight thoracic vertebrae (T8). A T8 laminectomy was performed carefully under magnification and the dural sac identified. Spinal cord compression was performed using a $6.7 \mathrm{~mm}$ clip $\left(\mathrm{Vicca}^{\circledR}\right)$ with a closing pressure of $50 \mathrm{~g} / \mathrm{strength}$ during 60 seconds. ${ }^{15}$ (Figure 1) After the injury, the incision was sutured with mononylon 3-0 and the antiseptic solution was applied to the incision. Postoperatively, ceftriaxone (100 mg/kg, i.p.) and tramadol (1.5 mg/kg s.c.) were administered and subcutaneous hydration was given with $10 \mathrm{ml}$ of $0.9 \%$. The Credé maneuver was performed at the end of the procedure to empty the bladder. Postoperative care included: Credé maneuver twice daily, daily inspection of the skin; pressure ulcer prevention; and fluid restriction during the acute period and at night, to decrease bladder strain. Rats were weighed once a week, and nutrition was limited to 20 grams to avoid weight gain. In case of anorexia, $10 \mathrm{ml}$ of warm normal saline were administered intraperitoneally. Urinary tract infection, manifested by hematuria with pus or cloudy urine, was treated with amoxicillin with clavulinic acid (2 mg/100 g i.p.). ${ }^{16,17}$ The rats with urinary infection that were not getting better with antibiotic treatment and becoming progressively sicker were excluded from the study.

\section{Preparation of Bone Marrow Mononuclear Cells}

BMMCs were obtained from male Wistar rats with the $Y$ chromosome used as a reporter of transplanted cells. Bone marrow was extracted from the humerus, femur, and tibia by flushing with 10,000 $\mathrm{U}$ of heparin in 50ml of Dulbecco's phosphate buffered saline (DPBS). Extracts were centrifuged at $400 \mathrm{Xg}$ for 10 minutes. Cell pellets were

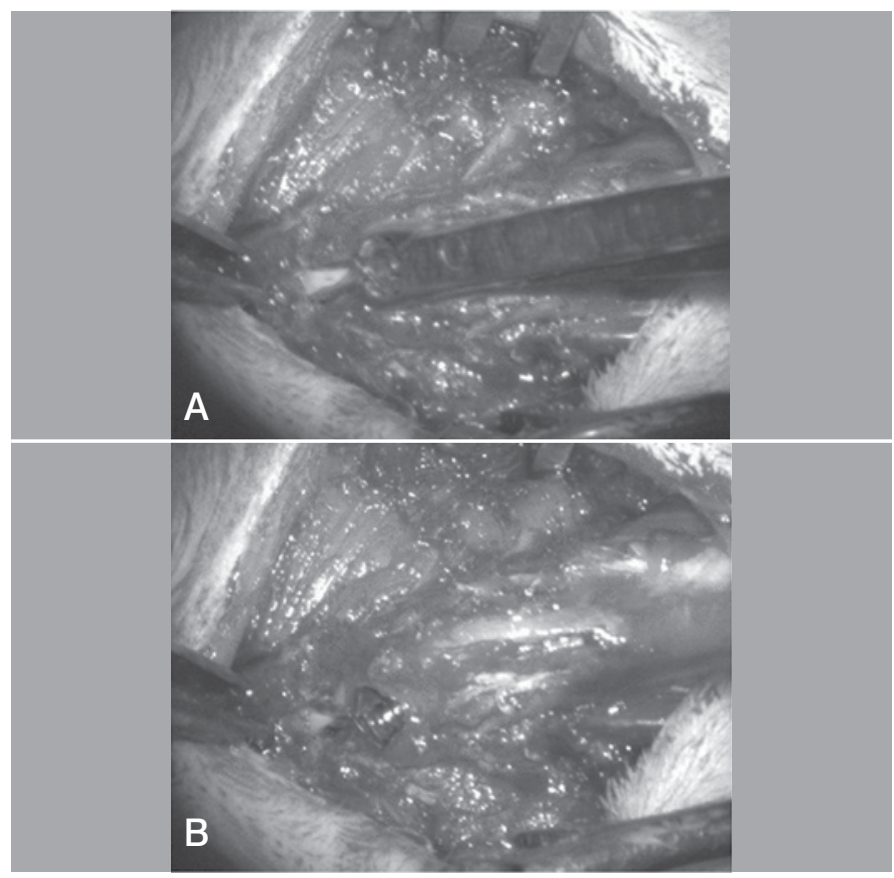

Figure 1. Surgical procedure steps showing in A, spinal cord and dural sac identification after careful muscle dissection and T8 laminectomy and B, spinal cord clipping was performed during 60 seconds.

resuspended with RPMI-1640 and fractionated on a density gradient generated by centrifugation at $400 \mathrm{Xg}$ over a Ficoll-Paque solution (Histopaque 11191, Sigma Aldrich, St. Louis, MO, USA). The mononuclear fraction over the Ficoll-Paque layer was collected and washed twice with DPBS. Cell concentrations were determined with a Neubauer-counting chamber with the number of viable cells determined by Trypan Blue exclusion. For the detection of surface antigen, BMMCs were incubated with conjugated antibodies against CD34, CD11b, CD117, CD45, and Sca1. Labeled cells were collected and analyzed using a FACSCalibur cytometer.

\section{Lumbar Puncture}

BMMCs or saline solution were infused into the subarachnoid space via LP. A volume of $40 \mathrm{uL}$ containing $10^{6}$ cells was used. ${ }^{10-13}$ After anesthesia and skin preparation, the lumbar spinous processes of the L6 and S2 were palpated and a 27G needle was introduced into the subarachnoid space with a slight flexion of the animal's body, to facilitate access to the spinal canal. The correct needle positioning in the subarachnoid space was determined by the contraction of the tail at the time of needle insertion or cerebrospinal fluid leakage. Cell infusion was performed for 1 minute to avoid reflux. LP transplantation was performed twice at 48 hours and 9 days after SCl.

\section{Evaluation of Motor Function}

Hind limb motor function was evaluated using the BBB score. ${ }^{14}$ The animals were assessed 24 hours postoperatively; only those that scored less than 3 were included in the study. After the procedure, rats were evaluated once a week for 21 days. The rats were placed in an open field and videotaped for five minutes. The films were subsequently analyzed and the animals were scored by two evaluators. If there was disagreement between evaluators, a third reviewer was consulted.

\section{Histology}

On day 21, after evaluation of motor function, animals were euthanized with high doses of $2 \%$ xylazine $(0.1 \mathrm{ml} / \mathrm{g})$ and $10 \% \mathrm{ke}$ tamine $(0.22 \mathrm{ml} / \mathrm{g})$ intraperitoneally. Nine rats were perfused with saline followed by $4 \%$ paraformaldehyde immersion for 24 hours. The spine was carefully dissected and the spinal cord was removed. A piece of spinal cord, measuring $1 \mathrm{~cm}$, was dissected to perform 
the histological analysis, the main lesion produced in our study was located in the center of the piece. The next day the spinal cords were placed in 30\% sucrose for dehydration for an additional 24 hours. Finally, the spinal cords were frozen in isopentane previously cooled in liquid nitrogen, acclimated in a cryostat (Cryotome ${ }^{\circledR}$ $\mathrm{SME}$, Shandon, Englant) sectioned at $-20^{\circ} \mathrm{C}$ at $30 \mu \mathrm{m}$. All sections were processed using the Nissl technique. ${ }^{18}$ The images of these sections were digitized using a stereomicroscope (Stemi SV6, Zeiss, Germany), coupled with a CCD camera (Pixera 1.2, Pixera, Pixera Corporation, CA, USA) and analyzed by software Image Pro Plus 6.1 (Media Cybernetics, San Diego, CA, USA). The sections were classified as lesioned or intact. The sections were considered lesioned when they did not have a clear anatomical definition between grey and white matter and consequently presented a "reticular" aspect. The number of injured sections was used to estimate the length of lesion in an adaptation of previously published protocols. ${ }^{19,20}$

\section{Y-Chromosome detection using Polymerase Chain Reaction}

The polymerase chain reaction (PCR) analysis was performed in order to identify the presence of transplanted BMMCs in the spinal cords. Three rats were subjected to the injury model: 3 received BMMC transplantation by LP 48 hours and 9 days after injury. Twenty-four hours after the last transplantation, rats were euthanized and samples of the spinal cord collected. We used forward primer 5'-direct atggagaattctgaggaggaga-3' and reverse primer 5'-attcacaaagctgacctccagttg-3', complementary to the DNA sequence corresponding to a specific region of the Y-chromosome, generating a PCR product of $524 \mathrm{bp}$. We performed a new direct amplification using the primer 5'-cagagcccaggtgctcctgctg-3' and reverse 5'-ctcctccattttagatctgcgttc-3', generating a PCR product of $324 \mathrm{bp}$, using a nested PCR technique. A positive control sample (Y-chromosome + DNA extracted from a male rat) and a negative control (no Y-chromosome + DNA extracted from a female rat) were assayed with experimental samples in every reaction. Amplified products were detected by gel electrophoresis (agarose 2\% containing ethidium bromide) and viewed under ultraviolet light.

\section{Statistical analysis}

Data are presented as the mean \pm standard deviation (SD) or the mean \pm standard error of the mean (SEM) as indicated in the Figure Legends. Two-way analysis of variance (ANOVA) followed by the Bonferroni post-hoc test was used to analyze data obtained by the BBB test. Data obtained on histology were analyzed using one-way ANOVA followed by the Tukey Test and Student's t test). Statistical analysis was performed with PrismGraph 5.0 software (Graph-Pad Software, San Diego, CA). An $\alpha$ level of 0.05 was applied and a p-value of less than 0.05 was considered statistically significant.

\section{RESULTS}

\section{Recovery of motor function}

The BBB scores in the sham group were 21 while animals that underwent compression scored a maximum of $7 \pm 0.5$, which showed that the SCI model performed by clip compression was efficient.

Post-hoc analysis indicated that function improved significantly beginning week 2 after transplantation. The BBB had significantly improved in rats treated with BMMCs by LP compared with controls in the last two evaluations, on days 14 and $21(p<0.001)$. (Figure 2)

\section{Lesional Area Measurement}

The animals treated with BMMCs by LP have similar lesional areas when compared with the control group.

\section{Migration of donor-derived BMMCs to the site of injury}

The PCR analysis was performed on 3 spinal cord samples from injured rats transplanted with BMMCs and there was a positive finding for the $342 \mathrm{bp}$ band, corresponding to the specific sequence of the Y-chromosome after the second amplification at the A3 column. (Figure 3)

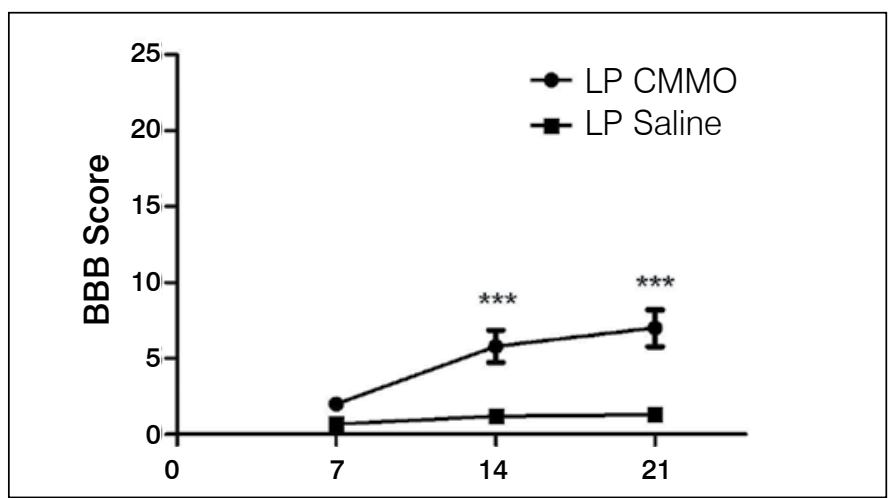

Figure 2. BBB significantly improved in rats treated with BMMCs by LP compared with controls in the last two evaluations, on days 14 and $21 * * * p<0,001$. Data are expressed as mean + SE of each day's observation Bonferroni test after two-way ANOVA with repeated measures, $n=6$ per group.

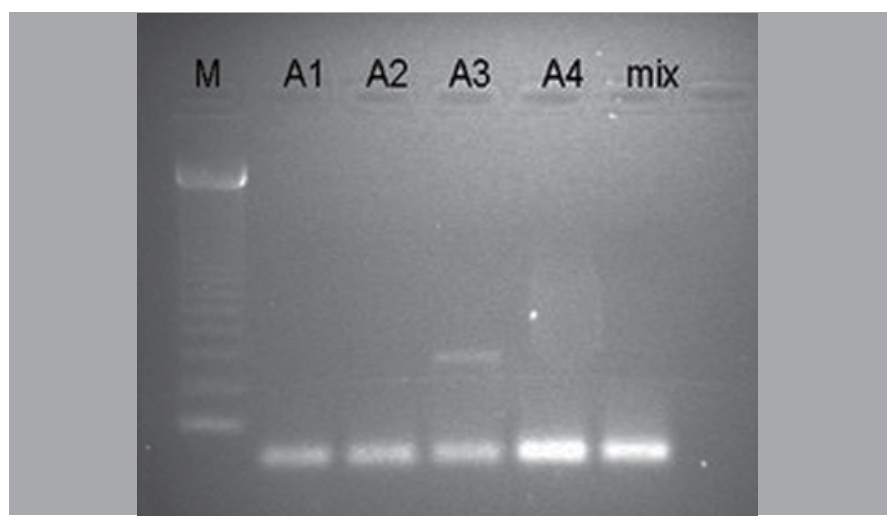

Figure 3. BMMC migration and identification at lesion site by PCR from a rat transplanted via double LP - A3 column.

\section{DISCUSSION}

Studies have shown neurological benefits by using BMSC in experimental $\mathrm{SCI}$ models and also could present the cellular migration to the lesion and the differentiation in neurons and oligodendrocytes. ${ }^{5,6}$

In order for SC therapy to be available in clinical practice, the most effective and reasonable route of administration must be established. In this way, despite some controversies about which is the best delivery in animal studies, there seems to be a tendency for administration by DI approach to result in more neurological improvement and grafting at the lesion site. 5,13,21,22

Vaquero et al. ${ }^{22}$ reported a more efficient implantation of the stem cells via DI than intravenous injection at the lesion site in a chronic model of SCl. Likewise, Paul et al. ${ }^{13}$ reported that a single dose of stem cells administered by DI resulted in better neurological improvement and a higher number of implantation cells when compared with the injection through the subarachnoid space or the intravenous route. The drawback of this study is the lack of a control group. However, Kang et al. ${ }^{23}$ showed that the fate of transplanted allogenic mesenchymal stem cells derived from bone marrow and the expression of neuronal growth factors are different between intravenously or DI routes in animal SCl. The mean score of the BBB motor scales was better in the intravenous group, when compared to the control and DI groups. ${ }^{23}$ We can conclude that the best route for the delivery of stem cells in the SCI model is still unknown.

Fujioka et al. ${ }^{24}$ reported a significant functional recovery in $\mathrm{SCl}$ after CD 133 cells were transplanted by LP when compared with the control group. In our study, the BMMCs transplanted group with two LP administration showed better BBB results starting in the second postoperative week, while saline controls had low scores throughout the 21-day follow-up period.

In an animal SCI model, Neuhuber et al. ${ }^{21}$ showed that although motor 
recovery was greater after a single transplantation of neural precursor cells (NPCs) using a DI than in administration by LP, the neurological improvement in the DI and LP group was significantly better than the control groups and a similar number of SC was found in the injury site regardless of the route used. In general, this represents the opinions found in the literature which are that the grafting of SC seems to be present at the injury site independently of administration route. In other words, these cells had been found at the injury site after being transplanted by intravenous, intraparenchymal, intrathecal, and intraventricular routes. ${ }^{11,13,22,25}$

Some studies used the LP approach to inject the stem cells into the subarachnoid space and for the subsequent evaluation of their implantation..$^{12,13,26}$ Paul et al..$^{13}$ reported an SC implantation rate of $4.1 \%$ and $3.4 \%$, respectively, 4 and 21 days after LP infusion. Mothe et $\mathrm{al}^{26}$ reported that the NPCs and BMSC transplanted by LP, one week after the surgery, were found at the lesion $\mathrm{SCl}$ site.

Bakshi et al. ${ }^{10}$ found that $1 \times 110^{6}$ BMSCs administered by a single $\mathrm{LP}$ in a mild $\mathrm{SCl}$ model had an effective migration and implantation in the injured site, was capable of reducing the cavity lesion when administered up to two weeks post-injury, and that larger volumes of cells infusions did not correlate with increased implantation. Nevertheless, Lepore et al. ${ }^{12}$ reported, in a hemisection ablation model using a PL delivery, that the migration and implantation rates of NPCs was greater in the group receiving multiple transplantation than with single transplantation. In the present study $10^{6}$ BMMCs were injected at two different times of administration in the subarachnoid space by LP technics and it was observed that the migration and the implantation of these cells could be verified, as well as the motor recovery.

Although these studies show a variety of neurological improvements and SC migration and implantation using the direct or subarachnoid approach, it is difficult to perform a direct comparison and come to a clear conclusion. This is due to the fact that some of these studies did not have control groups for the vehicle and the type of cell, ${ }^{13}$ and the animal breed, the severity of injury ${ }^{10,21}$ and the time of observation were different from those used in the present work. In our study, the histological data showed a similar lesional area between the $\mathrm{BMMC}$ and control group. Although there was no statistical difference between the groups, the group treated with BMMCs showed better motor recovery. The difficulty in finding a relation between histology and neurological outcome could be one of the limitations of the present study. The histology technics used had a low specificity to identify the myelin reorganization at the injury site when compared with

\section{REFERENCES}

1. Ackery $A$, Tator $C$, Krassioukov A. A global perspective on spinal cord injury epidemiology. J Neurotrauma. 2004:21(10):1355-70

2. Sekhon LH, Fehlings MG. Epidemiology, demographics, and pathophysiology of acute spina cord injury. Spine (Phila Pa 1976). 2001;26(Suppl 24):S2-12.

3. Boido M, Rupa R, Garbossa D, Fontanella M, Ducati A, Vercelli A. Embryonic and adult stem cells promote raphespinal axon outgrowth and improve functional outcome following spinal hemisection in mice. Eur J Neurosci. 2009:30(5):833-46.

4. Urdzíková L, Jendelová P, Glogarová K, Burian M, Hájek M, Syková E. Transplantation of bone marrow stem cells as well as mobilization by granulocyte-colony stimulating factor promotes recovery after spinal cord injury in rats. J Neurotrauma. 2006;23(9):1379-91.

5. Chopp M, Zhang XH, LiY, Wang L, Chen J, Lu D, et al. Spinal cord injury in rat: treatment with bone marrow stromal cell transplantation. Neuroreport. 2000:11(13):3001-5.

6. Hofstetter CP Schwarz EJ, Hess D, Widenfalk J, El Manira A Prockop DJ, et al. Marrow stromal cells form guiding strands in the injured spinal cord and promote recovery. Proc Nat Acad Sci U S A. 2002;99(4):2199-204.

7. Himes BT, Neuhuber B, Coleman C, Kushner R, Swanger SA, Kopen GC, et al. Recovery of function following grafting of human bone marrow-derived stromal cells into the injured spina cord. Neurorehabil Neural Repair. 2006:20(2):278-96.

8. Karimi-Abdolrezaee S, Eftekharpour E Wang J, Morshead CM, Fehlings MG. Delayed transplantation of adult neural precursor cells promotes remyelination and functional neurological recovery after spinal cord injury. J Neurosci. 2006;26(13):3377-89.

9. Parr AM, Kulbatski I, Tator $\mathrm{CH}$. Transplantation of adult rat spinal cord stem/progenitor cells for spinal cord injury. J Neurotrauma. 2007;24(5):835-45.

10. Bakshi A, Barshinger AL, Swanger SA, Madhavani V, Shumsky JS, Neuhuber B, et al. Lumbar puncture delivery of bone marrow stromal cells in spinal cord contusion: a novel method for minimally invasive cell transplantation. J Neurotrauma. 2006:23(1):55-65.

11. Bakshi A, Hunter C, Swanger S, Lepore A, Fischer I. Minimally invasive delivery of stem cells for spinal cord injury: advantages of the lumbar puncture technique. J Neurosurg Spine. 2004;1(3):330-7.

12. Lepore AC, Bakshi A, Swanger SA, Rao MS, Fischer I. Neural precursor cells can be delivered into the injured cervical spinal cord by intrathecal injection at the lumbar cord. Brain Res. 2005;1045(1-2):206-16.

13. Paul C, Samdani AF Betz RR, Fischer I, Neuhuber B. Grafting of human bone marrow stromal cells into spinal cord injury: a comparison of delivery methods. Spine (Phila Pa 1976). 2009;34(4):328-34.

14. Basso DM, Beattie MS, Bresnahan JC. A sensitive and reliable locomotor rating scale for open field testing in rats. J Neurotrauma. 1995;12(1):1-21. a immunohistochemical study. This was consistent with the evidence that the reorganization of the spinal cord circuitry was independent of modifications in injury size and can explain the motor improvement. ${ }^{27}$

Assuming that the DI route is the best route to infuse the SC, the translation to clinical practice could be of some concern. The reason is that using this technique spinal surgery was required, there was a risk of neurological deterioration due to damage to the spinal cord by needle puncture and the intramedullary injection of SC volume, higher costs, possible spinal deformity secondary to a laminectomy, difficulty in distinguishing the normal anatomy because of bone or muscle injuries or previous surgeries, greater chances of cerebrospinal fluid fistula, inherent clinical risks, such as deep vein thrombosis and pulmonary embolism and difficulty in closing muscle and skin due to previous scar tissue. ${ }^{28}$ These problems may increase with subsequent injections, as further healing occurs. Thus, a study to verify the effectiveness of a minimally invasive route for SC delivery, like LP into the subarachnoid space is warranted.

The subarachnoid route allows multiple applications by minimally invasive technics which can supplant the theoretical advantage of the primer. In patients receiving transplants by the LP route, the complication that can be expected is a headache, although this is less likely to occur, since removal of spinal fluid is minimal. The present study showed that multiple applications of BMMCs via LP, in the acute stage of injury, may be an alternative for SCI treatment.

\section{ACKNOWLEDGEMENT}

This work has no conflict of interest and was supported by grants from the Brazilian Agencies Coordenação de Aperfeiçoamento de Pessoal de Nível Superior (CAPES), Fundação de Amparo a Pesquisa do Rio Grande do Sul (FAPERGS), Pontifícia Universidade Católica do Rio Grande do Sul (PUCRS) and Pandurata Ltda.

E. L. Kaminski, G.T. Venturin and P.B. Bagatini were recipients of a Master's scholarship from CAPES or National Council of Scientific and Technological Development (CNPq). J. C. DaCosta, A. Falavigna and L. L. Xavier are researchers of the National Council of Scientific and Technological Development (CNPq).

All authors declare no potential conflict of interest concerning this article.

15. Rivlin AS, Tator $\mathrm{CH}$. Effect of duration of acute spinal cord compression in a new acute cord injury model in the rat. Surg Neurol. 1978;10(1):38-43.

16. Liu J, An H, Jiang D, Huang W, Zou H, Meng C, Li H. Study of bacterial translocation from gut after paraplegia caused by spinal cord injury in rats. Spine (Phila Pa 1976). 2004:29(2):164-9.

17. Santos-Benito FF, Muñoz-Quiles C, Ramón-Cueto A. Long-term care of paraplegic laboratory mammals. J Neurotrauma. 2006;23(3-4):521-36.

18. Costa-Ferro ZS, Vitola AS, Pedroso MF, Cunha FB, Xavier LL, Machado DC, et al. Prevention of seizures and reorganization of hippocampal functions by transplantation of bone marrow cells in the acute phase of experimental epilepsy. Seizure. 2010;19(2):84-92

19. Marret S, Mukendi R, Gadisseux JF, Gressens P, Evrard P. Effect of ibotenate on brain development: an excitotoxic mouse model of microgyria and posthypoxic-like lesions. J Neuropathol Exp Neurol. 1995;54(3):358-70.

20. Rousset Cl, Kassem J, Olivier P, Chalon S, Gressens P, Saliba E. Antenatal bacterial endotoxin sensitizes the immature rat brain to postnatal excitotoxic injury. J Neuropathol Exp Neurol. 2008:67(10):994-1000.

21. Neuhuber B, Barshinger AL, Paul C, Shumsky JS, Mitsui T, Fischer I. Stem cell delivery by lumbar puncture as a therapeutic alternative to direct injection into injured spinal cord. J Neurosurg Spine. 2008;9(4):390-9.

22. Vaquero J, Zurita M, Oya S, Santos M. Cell therapy using bone marrow stromal cells in chronic paraplegic rats: systemic or local administration? Neurosci Lett. 2006:398(1-2):129-34.

23. Kang ES Ha KY Kim YH. Fate of transplanted bone marrow derived mesenchymal stem cells following spinal cord injury in rats by transplantation routes. J Korean Med Sci. 2012;27(6):586-93.

24. Fujioka Y, Tanaka N, Nakanishi K, Kamei N, Nakamae T, Izumi B, et al. Magnetic field-based delivery of human $C D 133$ cells promotes functional recovery after rat spinal cord injury. Spine (Phila Pa 1976) .2012:37(13):E768-77.

25. Kennedy P Scott-Wilson U Sandhu N. The psychometric analysis of a brief and sensitive measure of perceived manageability. Psychol Health Med. 2009;14(4):454-65.

26. Mothe AJ, Bozkurt G, Catapano J, Zabojova J, Wang X, Keating A, et al. Intrathecal transplantation of stem cells by lumbar puncture for thoracic spinal cord injury in the rat. Spinal Cord. 2011;49(9):967-73

27. Courtine G, GerasimenkoY, van den Brand R, Yew A, Musienko P, Zhong H, et al. Transformation of nonfunctional spinal circuits into functional states after the loss of brain input. Nat Neurosci. 2009;12(10):1333-42

28. Deutsch H, Haid RW, Rodts GE, Mummaneni PV. Postlaminectomy cervical deformity. Neurosurg Focus. 2003;15(3):E5. 